\title{
The Mechanical Properties of Fly Ash Concrete Reinforced with Bamboo Fibers
}

\author{
Henock Eshetu Aweke ${ }^{1}$, Tesfaye Alemu Mohammed ${ }^{2}$ \\ ${ }^{1}$ Department of Civil Engineering, (Construction Technology and Management), Addis Ababa Science and Technology University, Addis \\ Ababa, Ethiopia \\ ${ }^{2}$ Department of Civil Engineering, (Structural Engineering), Addis Ababa Science and Technology University, Addis Ababa, Ethiopia
}

Email address:

henkeshetu99@gmail.com (H. E. Aweke), tesfaye.alemu@aastu.edu.et (T. A. Mohammed)

\section{To cite this article:}

Henock Eshetu Aweke, Tesfaye Alemu Mohammed. The Mechanical Properties of Fly Ash Concrete Reinforced with Bamboo Fibers. American Journal of Construction and Building Materials. Vol. 4, No. 1, 2020, pp. 22-26. doi: 10.11648/j.ajcbm.20200401.14

Received: March 22, 2020; Accepted: April 3, 2020; Published: May 15, 2020

\begin{abstract}
In addition to the economic advantages, using fly ash in cement has enormous effect on the mechanical properties of the concrete. Moreover, Researchers have identified that the addition of fibers to concrete increases its mechanical properties. Therefore, Better concrete product using both fly ash and fibers especially natural fibers which are more economical and eco-friendlier than the other fibers for an improved concrete strength production is the major aim of this research. This experimental investigation had been undertaken to study a fly ash concrete reinforced with bamboo fibers. The optimum percentage of fly ash to replace cement was first determined by compressive strength test for different percentages by weight of fly ash substitution. After that, mechanical properties of the fly ash concrete were studied with the addition of three different percentages of bamboo fibers. Mix designs were formulated for all percentage and then, Specimens were casted and tested for computing compressive strengths, indirect tensile strengths and flexural strengths for $7^{\text {th }}$ and $28^{\text {th }}$ day period. In the experiments, non-fibrous $25 \%$ fly ash substituted with cement concrete (the optimum percentage which was first determined using compressive strength) were compared with the $25 \%$ flyash substituted with cement for the individual fibers percentages. The standard $150 \mathrm{~mm}$ cube compressive strength of bamboo fiber reinforced Fly Ash Concrete (BFRFAC) with $0.10 \%$ addition of bamboo fiber by weight of concrete showed an increment of $12.44 \%$, Whereas bamboo fiber reinforced Fly Ash Concrete with $0.2 \%$ and $0.30 \%$ addition of bamboo fiber by weight of concrete showed a compressive strength reduction of $9.33 \%$ and $33.03 \%$ respectively compared to non-fibrous fly ash concrete. Bamboo fiber reinforced Fly Ash Concrete with $0.10 \%$ and $0.20 \%$ bamboo fiber addition by weight of concrete showed an increment in mean split tensile strength of $5.81 \%$ and $0.12 \%$ respectively; whereas $0.30 \%$ additions of bamboo fiber by weight of concrete showed split tensile strength reduction of $14.54 \%$ compared to non-fibrous fly ash concrete. Mean Flexural strength of bamboo fiber reinforced Fly Ash Concrete with $0.10 \%, 0.20 \%$ and $0.30 \%$ addition of bamboo fiber by weight of concrete showed an increment by $2.48 \%, 5.98 \%$ and $7.80 \%$ compared to non-fibrous fly ash concrete respectively.
\end{abstract}

Keywords: Fly Ash, Bamboo Fiber, Compressive Strength, Split Tensile Strength, Flexural Strength

\section{Introduction}

Concrete is world most used construction material with its main ingredient, cement, with its fabrication accounts for 5 to $10 \%$ of the global carbon emission. This has driven scientists to create innovative alternatives with smaller carbon footprints. Therefore, scientists and researchers are studying additions and material replacements to raise the concrete's performance to reduce its consumption, thus lowering the overall environmental impact.
Industrial and agricultural waste by-products such as fly ashes ground granulated slag and rice husk ashes are used as supplementary cementitious materials in concrete. The incorporation of supplementary cementitious materials not only improves the mechanical properties of concrete but also reduces the cement consumption by replacing part of cement with these materials [1]. Over the last decades intensive research and development works has been taking place in the field of fiber reinforced concrete. In developing countries, the idea of using fibers to improve strength and ductility of the 
brittle material has been adopted for thousands of years with the use of straw, horse-hair, etc. in bricks, concretes and other products. The possibility of using these fibers in normal concrete, provided simple production methods could be employed, would obviously offer a unique low-cost local material for concreting and other purposes.

The function of fibers in concrete is mainly to inhibit crack initiation and propagation and improve the mechanical properties of concrete [2] such as compressive strength, tensile strength, flexural strength, impact resistance and toughness. Addition of fibers provides better performance for the concrete while flyash in the mixture may adjust the workability and improve strength gain in later ages [3].

Fly ash is the material collected in the dust-collection systems that remove particles from the exhaust gases of power plants that burn pulverized coal. It consists mostly of small spheres of glass of complex composition involving silica, ferric oxide, and alumina.

It is a finely-divided amorphous alumino-silicate with varying amounts of calcium, which when mixed with portland cement and water, will react with the calcium hydroxide released by the hydration of portland cement to produce various calcium-silicate hydrates (C-S-H) and calcium-aluminate hydrates. Some fly ashes with higher amounts of calcium will also display cementitious behavior by reacting with water to produce hydrates in the absence of a source of calcium hydroxide. These pozzolanic reactions are beneficial to the concrete in that they increase the quantity of the cementitious binder phase (C-S-H) and, to a lesser extent, calcium-aluminate hydrates, improving the long term strength and reducing the permeability of the system. Both of these mechanisms enhance the durability of the concrete.

Fibers are small discrete reinforcing inputs produced from various materials like steel, glass, carbon and natural sources in various shapes and sizes [5]. Plain concrete possesses two major drawbacks as a structural material. They behave in brittle or semi brittle fashion and possess a very low tensile strength. Compared to other construction materials, it possesses a low specific modulus, limited ductility and little resistance to cracking. Micro cracks develop in the material during its manufacture due to inherent volumetric and micro structural changes, and an essential discontinuous, heterogeneous system thus exists even before any external load is applied. In addition to the low tensile strength, the material possesses little resistance to tensile crack propagation in turn results in low fracture toughness and limited resistance to impact and explosive loading. It has been found that addition of small closely spaced and uniformly dispersed fibers to concrete would act as crack arrestors and substantially improve the tensile strength and other properties of concrete. This type of concrete is called as fiber reinforced concrete $[4,6]$.

Therefore, in this study, the properties of both fresh and hardened fly ash concrete reinforced with bamboo fibers tried to be studied.

\section{Materials and Methods}

Materials used in the experiment were Cement, fly ash (class F), fine and course aggregate, bamboo fiber and water.

\subsection{Materials}

\subsubsection{Cement and Water}

From locally produced cements 42.5R Dangote Ordinary Portland Cement was used.

The water used for mixing and curing of concrete should be free from materials that significantly affect concrete quality. Therefore, potable water was used both for mixing and curing.

\subsubsection{Fine Aggregate}

In this specific research work, local river sand was used as fine aggregate. Physical properties of fine aggregates like specific gravity and absorption capacity (ASTM C 128), fineness modulus (ASTM C 136), silt content and moisture content (ASTM C 566) were determined. The physical properties of sample fine aggregate are presented in the table below.

Table 1. Physical properties fine aggregate.

\begin{tabular}{lll}
\hline No & Physical properties tests & Results \\
\hline 1 & Silt content & $2.41 \%$ \\
2 & Moisture content & $3.31 \%$ \\
3 & Absorption capacity & $3.73 \%$ \\
4 & Bulk specific gravity & 2.35 \\
& Bulk specific gravity (SSD) & 2.44 \\
& Bulk specific gravity (Apparent) & 2.58 \\
5 & Fineness Modulus & $2.65 \%$ \\
\hline
\end{tabular}

\subsubsection{Coarse Aggregate}

Basaltic crushed rock was used as coarse aggregate in sample preparation for this specific experimental study. The maximum aggregate size of coarse aggregate was $20 \mathrm{~mm}$. Physical properties of coarse aggregate; like specific gravity and absorption capacity (ASTM C 127), moisture content (ASTM C 566) and sieve analysis (ASTM C136) were determined.

The physical properties of course aggregate are summarized in the table below.

Table 2. Physical properties course aggregate.

\begin{tabular}{lll}
\hline No & Physical properties tests & Results \\
\hline 1 & Maximum size & $20 \mathrm{~mm}$ \\
2 & Moisture content & $1.63 \%$ \\
3 & Unit weight & $1887.24 \mathrm{~kg} / \mathrm{m}^{3}$ \\
4 & Absorption capacity & $1.90 \%$ \\
5 & Bulk specific gravity & 2.85 \\
& Bulk specific gravity (SSD) & 2.91 \\
& Bulk specific gravity (Apparent) & 3.01 \\
6 & Fineness Modulus & $1.97 \%$ \\
\hline
\end{tabular}

\subsubsection{Fly Ash (Class F)}

Fly ash from $\mathrm{C}$ and E BROTHERS steel company (located in Debrezeyt) was used which is a by-product of a bituminous coal to manufacture reinforcement bars. The fly ash used was ASTM C616-03 or ACI-232.2R Class F Flyash which is classified as low calcium flyash or ASTM class F 
flyash.

\subsubsection{Bamboo fiber}

Bamboo plants for this study were collected from SNNP region, Gurage Zone, a place called Sebatbet. These bamboo plants are of highland bamboo (Yushinia Alphina) species. The structure of bamboo culm is hollow cylinder, and it consists a serious of segmented part called internode that are adjoined by respective node. The characteristics of this bamboo stem has a diameter of $8-10 \mathrm{~cm}$, length of internode ranges between $15-50 \mathrm{~cm}$, thickness of bamboo stem about 1$2 \mathrm{~cm}$ with height of $10-15 \mathrm{~m}$.

\subsection{Sample Preparation}

A Fly ash replacement percentage of 15, 20, 25 and 30 were used in this study. This percentage of replacements was chosen based on the recommendation on ACI $211.4 \mathrm{R}-8$, for class F Fly ash type it is recommended to use $15-25 \%$ of replacement to cement. In addition to that the percentages for the addition of bamboo fibers were used based on earlier researches.

The samples were casted for compressive strength test, splitting tensile strength test and flexural strength test. For each of the tests three (and at least two for flexural strength test) specimens were kept in order to show the repeatability of the result through which to minimize the effect of extraneous or uncontrollable variable. The number of samples for this study was 54 cubes, 24 cylinders and 16 beams, totally 94 samples were tested.

\section{Results and Discussion}

\subsection{Chemical Compositions of Class F Fly Ash}

Table 3. Chemical properties of fly ash.

\begin{tabular}{lll}
\hline Properties & sample & ASTM-C-618 \\
\hline $\mathrm{SiO}_{2}$ & 63.12 & \\
$\mathrm{Al}_{2} \mathrm{O}_{3}$ & 26.78 & Min 70\% \\
$\mathrm{Fe}_{2} \mathrm{O}_{3}$ & 0.54 & \\
$\mathrm{CaO}$ & 0.15 & $\max 10 \%$ \\
$\mathrm{MgO}$ & 0.35 & \\
$\mathrm{Na} 2$ & 0.05 & \\
$\mathrm{~K}_{2} \mathrm{O}$ & 0.26 & \\
$\mathrm{SO}_{3}$ & 0.03 & \\
$\mathrm{P}_{2} \mathrm{O}_{5}$ & 0.08 & \\
$\mathrm{TiO}_{2}$ & 1.97 & $\max 3 \%$ \\
$\mathrm{H}_{2} \mathrm{O}$ & 2.56 & $\max 5 \%$ \\
$\mathrm{LOI}$ & 4.11 & \\
\hline
\end{tabular}

\subsection{Test Results}

\subsubsection{Compressive Strength Test to Determine Optimum Fly Ash Substitution Percentage}

In order to determine the optimum percentage of fly ash to substitute cement, compressive strength test was conducted with different percentage of fly ash substitution. The percentage substitution is based on ACI 211.4R-8.

The $28^{\text {th }}$ day mean compressive test results for various percentage of fly ash substitution to cement were compared with a plain concrete as shown in the figure below.

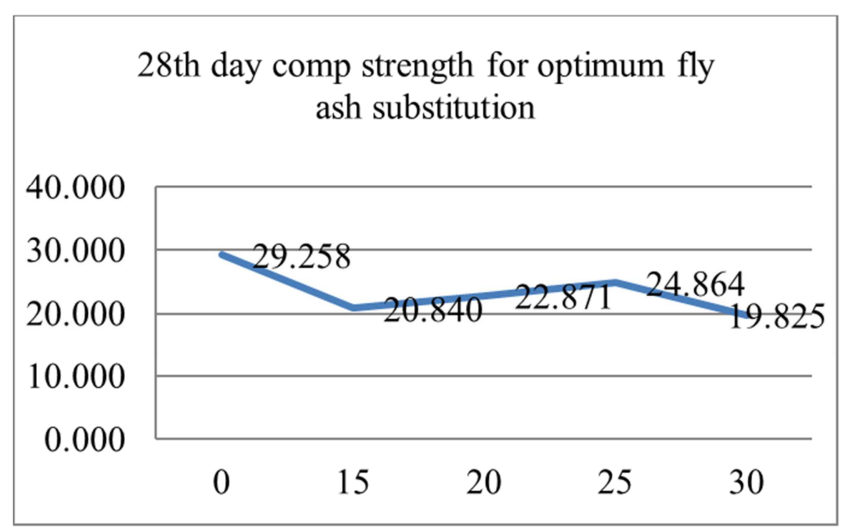

Figure 1. $28^{\text {th }}$ day compressive strength for different percentage of fly ash substitution.

Table 4. $28^{\text {th }}$ day compressive strength comparison for different percentage of fly ash substitution.

\begin{tabular}{llll}
\hline $\begin{array}{l}\text { \% Fly ash } \\
\text { substitution }\end{array}$ & $\begin{array}{l}\mathbf{2 8}^{\text {th }} \text { day Compressive } \\
\text { strength }\end{array}$ & \multicolumn{2}{l}{ \% Increase or decrease } \\
\hline 0 & 29.258 & - & \\
15 & 20.84 & $28.77 \%$ & decrease \\
20 & 22.871 & $21.83 \%$ & decrease \\
25 & 24.864 & $15.02 \%$ & decrease \\
30 & 19.825 & $32.24 \%$ & decrease \\
\hline
\end{tabular}

\subsubsection{Fresh Concrete Properties}

Among the fresh concrete properties slump test and fresh concrete density tests are investigated for each concrete mixture incorporating, $0 \%$ (with $25 \%$ fly ash substitution) (H0), $0.1 \%$ (with $25 \%$ fly ash substitution) (H1), $0.2 \%$ (with $25 \%$ fly ash substitution) (H2), and $0.3 \%$ (with $25 \%$ fly ash substitution) (H3) addition of bamboo fiber by weight of concrete.

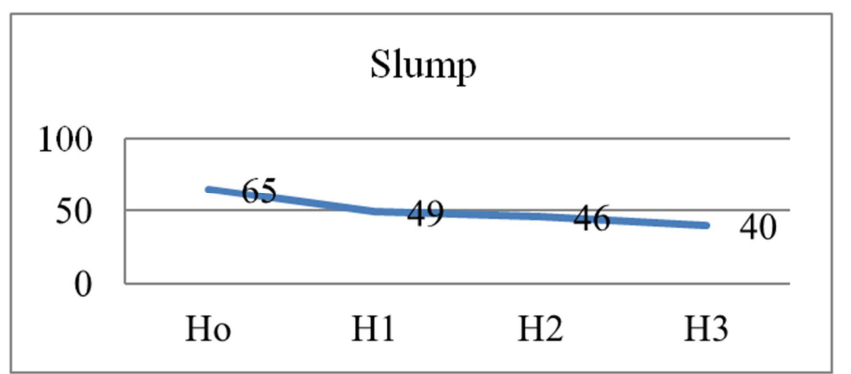

Figure 2. Slump results for different percentage of bamboo fibers.

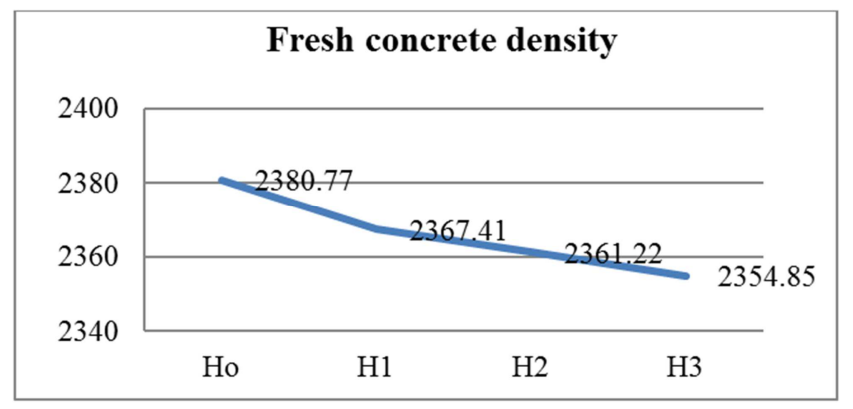

Figure 3. Fresh concrete densities for different percentage of bamboo fibers. 
Table 5. Slump and fresh concrete density comparison for different percentage of bamboo fibers.

\begin{tabular}{lllll}
\hline Mix & $\begin{array}{l}\text { Slump } \\
(\mathbf{m m})\end{array}$ & $\begin{array}{l}\text { Fresh concrete } \\
\text { density } \\
\left(\mathbf{K g} / \mathbf{m}^{3}\right)\end{array}$ & $\begin{array}{l}\text { \%Slump } \\
\text { increase or } \\
\text { decrease }\end{array}$ & $\begin{array}{l}\text { \%Fresh concrete } \\
\text { density increase } \\
\text { or decrease }\end{array}$ \\
\hline Ho & 65 & 2380.77 & - & - \\
H1 & 49 & 2367.41 & $24.62 \%$ & $0.56 \%$ \\
H2 & 46 & 2361.22 & $29.23 \%$ & $0.82 \%$ \\
H3 & 40 & 2354.85 & $38.46 \%$ & $1.09 \%$ \\
\hline
\end{tabular}

\subsubsection{Split Tensile Strength}

The splitting tensile strength test is an indirect tension test for concrete. It is carried out on a standard cylindrical specimen, tested on its side in diametric compression.

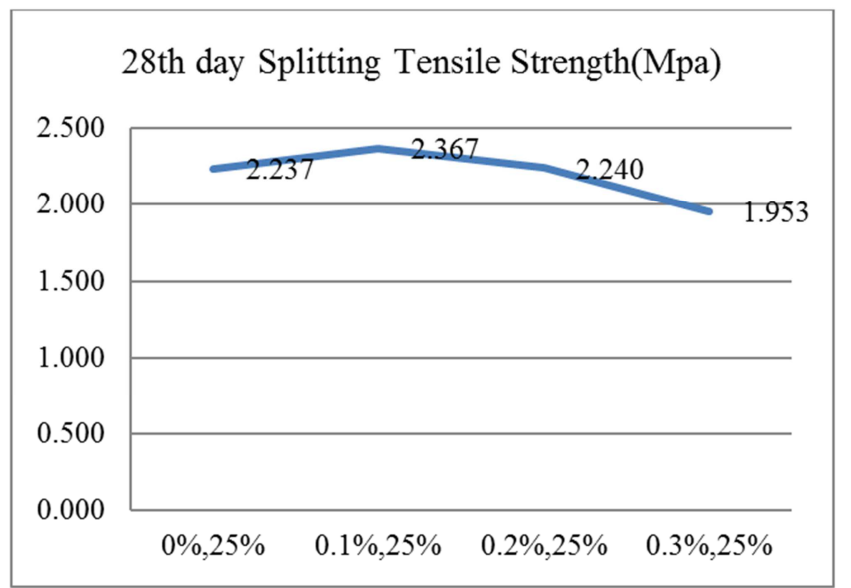

Figure 4. $28^{\text {th }}$ days splitting Tensile strength result for different percentage of Bamboo fiber.

Table 6. $28^{\text {th }}$ days splitting Tensile strength result comparison for different percentage of Bamboo fiber.

\begin{tabular}{llll}
\hline Mix & 28th day Splitting Tensile strength & \multicolumn{2}{l}{ \% Increase or decrease } \\
\hline Ho & 2.237 & - & \\
H1 & 2.367 & $5.81 \%$ & Increase \\
H2 & 2.24 & $0.12 \%$ & Increase \\
H3 & 1.953 & $14.54 \%$ & decrease \\
\hline
\end{tabular}

\subsubsection{Flexural Strength}

Flexural strength test gives another way for estimating tensile strength of concrete. During pure bending the member resisting the action is subjected to internal stresses (shear, tensile and compressive). For a bending force applied downward for a member simply supported at its two ends.

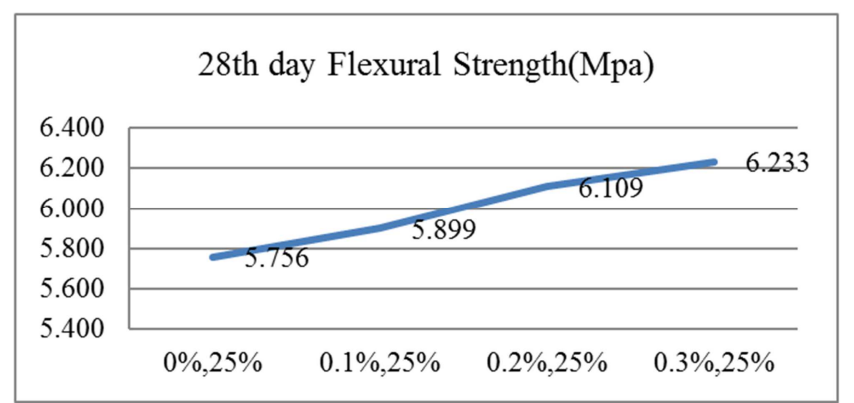

Figure 5. $28^{\text {th }}$ day Flexural strength result for different percentage of Bamboo fiber.
Table 7. $28^{\text {th }}$ day Flexural strength result comparison for different percentage of Bamboo fiber.

\begin{tabular}{llll}
\hline Mix & 28th day Flexural strength & \multicolumn{2}{c}{ \% Increase or decrease } \\
\hline Ho & 5.756 & - & \\
H1 & 5.899 & $2.48 \%$ & Increase \\
H2 & 6.109 & $5.98 \%$ & Increase \\
H3 & 6.233 & $7.80 \%$ & Increase \\
\hline
\end{tabular}

\subsubsection{Compressive Strength}

Three $150 \mathrm{~mm}$ sized cube samples were tested for each percentage addition of bamboo fiber namely: $0 \%$ (with $25 \%$ fly ash substitution), $0.1 \%$ (with $25 \%$ fly ash substitution), $0.2 \%$ (with $25 \%$ fly ash substitution), and $0.3 \%$ (with $25 \%$ fly ash substitution) were casted for the research.

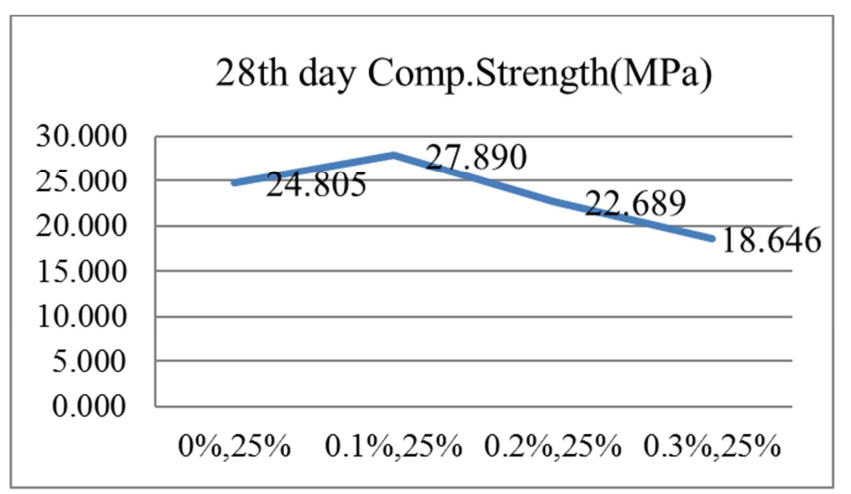

Figure 6. $28^{\text {th }}$ day Compressive strength result for different percentage of Bamboo fiber.

Table 8. $28^{\text {th }}$ day Compressive strength result comparison for different percentage of Bamboo fiber.

\begin{tabular}{llll}
\hline Mix & 28th day Compressive strength & \% Increase or decrease \\
\hline Ho & 24.805 & - & \\
H1 & 27.89 & $12.44 \%$ & Increase \\
H2 & 22.689 & $9.33 \%$ & decrease \\
H3 & 18.646 & $33.03 \%$ & decrease \\
\hline
\end{tabular}

\section{Conclusions and Recommendations}

\subsection{Conclusions}

The slump values showed a decrease for increasing in percentage of bamboo fiber but the mixes were within the acceptable range and workable.

The 28th day test results of BFRFAC incorporating $0.1 \%$, $0.2 \%$ and $0.3 \%$ bamboo fiber showed flexural strength increment compared to the reference non-fibrous fly ash concrete.

Compressive strengths with $0.1 \%$ addition of bamboo fiber by weight of fly ash concrete increased; while both $0.2 \%$ and $0.3 \%$ bamboo fiber addition reduced the compressive strength compared to the reference non-fibrous fly ash concrete.

The optimum Fly ash content varies on a case by case, here, the Substitution of cement with $25 \%$ of fly ash gave an optimum result from the other percentages using compressive strength test.

Among the three bamboo fiber additions under investigation, $0.10 \%$ bamboo fiber addition by weight of 
concrete could be concluded as the optimum percentage of bamboo fiber addition.

\subsection{Recommendations on the Current Study}

Addition of fibers like bamboo fibers provides better performance for the concrete while flyash in the mixture adjust the workability.

BFRFAC offers a holistic solution to the problem of meeting the increasing demands for concrete in the future in a sustainable manner at a reduced cost, and at the same time reducing the environmental impact.

Preparing guide lines; and necessary documents, updating standards, enforce regulations, and promoting use of cement substitution alternatives like fly ash and use of fibers and natural fiber reinforced concrete production is necessary.

\subsection{Recommendations on the Future Study}

Study on long term mechanical properties of BFRFAC. Study on the durability of BFRFAC.

\section{References}

[1] Mustard, J. N. and MacInnis, C., "The Use of Fly Ash in Concreteby Ontario Hydro." Engineering Journal, December, 1959 , pages 74 to 79 .

[2] J. Payá, J. Monzó, M. V. Borrachero, L. Díaz-Pinzón, and L. M. Ordónez, "Sugar-cane bagasse ash (SCBA): Studies on its properties for reusing in concrete production," J. Chem. Technol. Biotechnol., vol. 77, no. 3, pp. 321-325, 2002.

[3] P. Mehta and P. J. Monteiro, Concrete: Microstructure, Properties and Materials. 2006.

[4] Dr. Shakel Ahmad, Altamash Raza and Hina Gupta, "Mechanical Properties of Bamboo Fiber Reinforced Concrete".

[5] State-of-the-Art Report on Fiber Reinforced Concrete, reported by ACI committee 544 (ACI 544.1R-96), Reapproved 2002.
[6] Dr. Nataraja M. C. "Fiber Reinforced Concrete-Behaviour Properties and Application" Professor of Civil Engineering, Sri Jayachamarajendra College of engineering, Mysore-570, 2006.

[7] Gebler, S. H. and Klieger, P., "Effect of Fly Ash on the Durability of Air-Entrained Concrete," Proceedings of the 2nd International Conference on Fly Ash, Silica Fume, Slag, and Natural Pozzolans in Concrete, ACI SP-91, Vol. 1, American Concrete Institute, Farmington Hills, MI, 1986, pages 483 to 519.

[8] Pistilli, M. F., “Air-Void Parameters Developed by AirEntraining Admixtures as Influenced by Soluble Alkalis from Fly Ash and Portland Cement," ACI Journal, Proceedings V. 80, No. 3, May-June, 1983, pages 217 to 222.

[9] Malhotra, V. M. and Mehta, P. K., High-Performance, HighVolume Fly Ash Concrete. Supplementary Cementing Materials for Sustainable Development Inc., Ottawa, Canada, 2005, 124 pages.

[10] Bamforth, P. B., "In-Situ Measurement of the Effect of Partial Portland Cement Replacement Using Either Fly Ash or Ground-Granulated Blastfurnace Slag on the Performance of Mass Concrete," Proceedings of the Institution of Civil Engineers, Part 2, Vol. 69, September, 1980, pages 777 to 800.

[11] Lane, R. O., and Best, J. F., "Properties and Use of Fly Ash in Portland Cement Concrete," Concrete International, V. 4, No. 7, 1982, pages 81 to 92 .

[12] Yuan, R. L. and Cook, R. E., "Study of a Class C Fly Ash Concrete", Proceeding of the First International Conference on the Use of Fly Ash, Silica Fume, Slag, and Other By-Products in Concrete, ACI SP-79, Vol. 1, American Concrete Institute, Detroit, MI, 1983, pages 307 to 319.

[13] Ghosh, R. S. and Timusk, J., "Creep of Fly Ash Concrete", ACI Journals, Vol. 78, No. 5, Sep-Oct. 1981, pages 351 to 357.

[14] Tesfaye Reta Degefa.,"study on Mechanical Properties of Bamboo Fiber Reinforced Concrete", April 2017.

[15] Rooban Chakravarthy Sethu Mathavan.,'High volume Flyash Concrete Reinforced with Hybrid Fibers", December 2016. 